\title{
Clinical description of measles complications in adults in connection with changes in the functional state of the autonomic nervous system
}

\author{
Yu. Yu. Riabokon*A,C,E,F, S. O. Bilokobyla ${ }^{\mathrm{B}, \mathrm{C}}$, O. V. Riabokon ${ }^{\mathrm{A}, \mathrm{D}, \mathrm{E}}$ \\ Zaporizhzhia State Medical University, Ukraine \\ A - research concept and design; B - collection and/or assembly of data; C - data analysis and interpretation; D - writing the article; \\ $\mathrm{E}$ - critical revision of the article; $\mathrm{F}$ - final approval of the article
}

Aim of the work - to analyze measles complications in adults depending on the severity of the course and to find out their relationship with the functional state of the autonomic nervous system.

Results. Clinical manifestations of measles in adults under present conditions retain typical signs, but the feature is the preservation of Filatov-Koplik sign in the period of rashes $(77.1 \%)$. In severe course of measles more often $(P<0.01)$, than with a moderate course, scleroconjunctivitis with eye irritation, hoarseness, hemorrhagic manifestations, nausea, vomiting is recorded, the period of fever is prolonger. In most adult patients, measles had a complicated course $(70.5 \%)$, with the spectrum of complications mainly represented by the damage of the respiratory system (61.4\%) and the gastrointestinal tract $(43.8 \%)$. The frequency of development of complications and their range clearly depended on the severity of the disease. Complications such as bronchitis $(P<0.05)$ and pneumonia $(P<0.0001)$ were more common in patients with severe course of measles. Some patients with a severe course of measles developed such complications as pulmonary edema and left lung atelectasis. The most severe complications from the respiratory organs arose in pregnant women. Gastrointestinal complications such as hepatitis and enteritis were recorded in $43.8 \%$ of patients with measles, and the frequency of their development was also dependent on the severity of the disease $(P<0.01)$. The Mallory-Weiss syndrome was detected in one patient with a severe course of measles. Analysis of HRV indicators in adult patients with measles showed that in the presence of complications, the functional state of the ANS is characterized by a decrease in power in all regulatory units with the development of imbalance in the direction of sympathicotonia, compared with healthy people $(P<0.01)$. In patients with a complicated course of measles, indicators that characterize the total power of vegetative regulation, the parameter characterizing the humoral effects on the ANS $(V L F)$, were lower $(P<0.05)$, and part of the sympathetic effects in the general spectrum of vegetative regulation is higher $(P<0.05)$ than in patients without complications of this infection.

Conclusions. Clinical manifestations of measles in adults under present conditions remain typical, but in most adult patients $(70.5 \%)$ measles has a complicated character. The complications from the respiratory system $(61.4 \%)$ and the gastrointestinal tract $(43.8 \%)$ are often recorded, the frequency and spectrum of which depend on the severity of the disease. Complications from the nervous system and the organs of vision develop in single adult patients with severe course of measles. Disorders of ANS functional state play a role in depending of measles complications in adults. In the presence of complications, the functional state of ANS is characterized by a decrease in power in all regulatory units with the development of imbalance in the direction of sympathicotonia.

\section{Клінічна характеристика ускладнень кору в дорослих у взаємозв'язку зі змінами функціонального стану вегетативної нервової системи}

\section{Ю. Ю. Рябоконь, С. О. Білокобила, О. В. Рябоконь}

Мета роботи - проаналізувати ускладнення кору в дорослих залежно від тяжкості перебігу та з'ясувати їхній взаємозв'язок із функціональним станом вегетативної нервової системи.

Результати. Клініка кору в дорослих у сучасних умовах зберігає типові ознаки, особливістю перебігу є збереження симптому Філатова-Копліка в період висипань $(77,1 \%)$. Під час тяжкого перебігу частіше ( $p<0,01)$, ніж при середньотяжкому, реєструють склерокон'юнктивіт із різями в очах, осиплість голосу, геморагічні прояви, нудоту, блювоту, тривалішим є період гарячки. У більшості дорослих хворих кір мав ускладнений перебіг (70,5 \%), спектр ускладнень представлений переважно ураженням органів дихальної системи $(61,4 \%)$ та шлунково-кишкового тракту $(43,8 \%$ ). Частота розвитку ускладнень і їхній спектр чітко залежали від тяжкості перебігу захворювання. Ускладнення, як-от бронхіт $(p<0,05)$ та пневмонія ( $<<0,0001)$, частіше виникали у хворих із тяжким перебігом кору. В окремих хворих із тяжким перебігом кору розвинулись такі ускладнення, як набряк легень та ателектаз лівої легені. Найтяжчі ускладнення з боку органів дихання виникли у вагітних. Ускладнення з боку шлунково-кишкового тракту, як-от гепатит та ентерит, зафіксовані в 43,8 \% хворих на кір, а частота їхнього розвитку також залежала від тяжкості перебігу захворювання $(p<0,01)$. Синдром Мелорі-Вейса виявили в одного хворого з тяжким перебігом кору. Аналіз показників ВРС у дорослих хворих на кір показав, що за наявності ускладнень функціональний стан ВНС характеризується зниженням потужності в усіх ланках регуляції з розвитком дисбалансу в бік симпатикотонії порівняно зі здоровими $(p<0,01)$. У хворих з ускладненим перебігом кору показники, що характеризують загальну потужність вегетативної регуляції (SDNN, Total power), параметр, що характеризує гуморальні впливи на BHC (VLF), виявилися нижче $(p<0,05)$, а частка симпатичних впливів у загальному спектрі вегетативної регуляції (LF norm) - вище $(p<0,05)$, ніж у пацієнтів без ускладнень цієї інфекції.
Key words: adult measles, complications, heart rate variability.

Pathologia 2019; 16 (3), 339-344 DOI: 10.14739/2310-1237. 2019.3.188835

*E-mail: RyabokonZSMU@ gmail.com

Киючові слова: кір у Аорослих, ускладнення, варіабельність ритму серця.

Патологія. - 2019. T. 16, № 3(47). C. $339-344$ 
Висновки. Клінічні прояви кору в дорослих нині зберігають типові ознаки, але в більшості дорослих хворих (70,5 \%) кір має ускладнений характер. Найчастіше реєструють ускладнення з боку дихальної системи $(61,4$ \%) та шлунково-кишкового тракту (43,8 \%), частота та спектр яких залежить від тяжкості перебігу захворювання. Ускладнення 3 боку нервової системи та органів зору розвиваються в поодиноких хворих дорослих за умов тяжкого перебігу кору.

Порушення функціонального стану ВНС відіграють певну роль у формуванні ускладнень кору в дорослих. За наявності ускладнень функціональний стан ВНС характеризується зниженням потужності в усіх ланках регуляції з розвитком дисбалансу в бік симпатикотонії.

Ключевые слова: корь у взрослых, осложнения, вариабельность ритма сердца.

Патология. - 2019. T. 16, № 3(47). C. $339-344$

\section{Клиническая характеристика осложнений кори у взрослых во взаимосвязи с изменениями функционального состояния вегетативной нервной системы}

\section{Ю. Ю. Рябоконь, С. А. Белокобыла, Е. В. Рябоконь}

Цель работы - проанализировать осложнения кори у взрослых в зависимости от тяжести течения и выяснить их взаимосвязь с функциональным состоянием вегетативной нервной системы.

Результаты. Клинические проявления кори у взрослых сохраняют типичные признаки, особенностью течения является сохранение симптома Филатова-Коплика в период высыпаний $(77,1 \%)$. При тяжелом течении кори чаще (р<0,01), чем при среднетяжелом регистрировали склероконъюнктивит с резями в глазах, осиплость голоса, геморрагическую сыпь, тошноту, рвоту, более длительный лихорадочный период. У большинства взрослых корь протекала с осложнениями (70,5 \%), спектр осложнений представлен преимущественно поражением органов дыхательной системы (61,4 \%) и желудочно-кишечного тракта (43,8 \%). Частота развития осложнений и их спектр зависели от тяжести течения заболевания. Бронхит ( < 0,05) и пневмония ( $<$ <,0001) чаще возникали у больных с тяжелым течением кори. У отдельных пациентов с тяжелым течением кори развились отек легких и ателектаз левого легкого. Наиболее тяжелые осложнения со стороны органов дыхания отмечены у беременных. Осложнения со стороны желудочно-кишечного тракта, такие как гепатит и энтерит зафиксированы у 43,8 \% больных корью, а частота их развития также зависела от тяжести течения заболевания ( $<$ 0,01). Синдром Мэллори-Вейсса установлен у одного больного с тяжелым течением кори. Анализ показателей ВРС у взрослых больных корью показал, что при наличии осложнений функциональное состояние ВНС характеризуется снижением мощности во всех ветвях регуляции с развитием дисбаланса в сторону симпатикотонии по сравнению со здоровыми ( $<$ < 0,01). У больных с осложненным течением кори показатели, которые характеризуют общую мощность вегетативной регуляции (SDNN, Total power), параметр, характеризующий гуморальные влияния на BHC (VLF), были ниже ( $<0,05)$, а доля симпатических влияний в спектре вегетативной регуляции (LF norm) выше $(p<0,05)$, чем у больных без осложнений.

Выводы. Клиника кори у взрослых сохраняет типичные признаки, однако у большинства пациентов (70,5 \%) развиваются осложнения. Наиболее часто регистрируют осложнения со стороны дыхательной системы (61,4 \%) и желудочно-кишечного тракта (43,8 \%), частота и спектр которых зависит от тяжести течения заболевания. Осложнения со стороны нервной системы и органов зрения развиваются у единичных взрослых пациентов при тяжелом течении кори. Нарушения функционального состояния ВНС играют определенную роль в формировании осложнений кори у взрослых. При наличии осложнений функциональное состояние ВНС характеризуется снижением мощности во всех ветвях регуляции с развитием дисбаланса в сторону симпатикотонии.

Measles is a highly contagious viral infectious disease, which is guided by immune prophylaxis. In the early 2000s in the European Region, WHO set the goal of eliminating measles, that is, stopping the local circulation of the measles virus [1], but in 2017-2019 in Europe, particular in Ukraine, a significant increase in measles was noted. During the elimination period for the first time, measles ceased to be a childhood infection, and seasonal factors almost lost their impact on the internal dynamics of the epidemic process [2,3]. A significant increase in adult measles patients is due to the loss of protective antibodies after 10 years in most vaccinated ones, since only $36 \%$ of vaccinated individuals have these antibodies more longer [4].

In the periods of increased morbidity of measles, a part of the serious and complicated course of the disease naturally increases. Many studies show the dependence of the risk of developing complications from the age of patients, while it is believed that children of the first year of life and older adults often have a complicated course of the disease $[5,6]$. A considerable number of modern studies indicate a certain prevalence of adults among measles patients in modern conditions, in particular in
Germany [7], Italy [8], and Belgium [6]. The pathogenetic mechanisms of the development of complications in patients with measles are being studied today. On the one hand, the risk of developing a complicated course of measles correlates with the degree of immunosuppression expressiveness that develops in patients with measles. However, on the other hand, the measles virus can paradoxically cause the induction of a strong virus-induced specific immunity, which in the future remains viable [9].

Today, the pathogenetic mechanisms that determine the peculiarities of the course of diseases and their consequences are intensively studied. Particular attention is paid to the assessment of the functional state of the autonomic nervous system (ANS), which plays an important role in the course of various diseases, and heart rate variability (HRV) is considered as a measure of energy reserves of regulatory systems, is an indicator of stress tolerance, the quality of compensatory and adaptation mechanisms, and resources for recovery $[10,11]$. It is believed that cardiac rhythm is an indicator of deviations in regulatory systems that outperform not only hemodynamic but also metabolic disturbances. Therefore, changes in HRV can be considered as an early prognostic sign of the develop- 
ment of many pathological conditions, which enables us to assess the degree of adaptive capacity of the organism [12]. In recent years, a number of scientific studies have been published on the role of changes in the functional state of the ANS in infectious pathology [13,14], in particular in patients with measles [15], but the pathogenetic significance of these changes in the development of measles complications in adults remains unexplored.

\section{Aim}

Aim of the work - to analyze measles complications in adults depending on the severity of the course and to find out their relationship with the functional state of the autonomic nervous system.

\section{Materials and methods}

The study included 210 patients with measles aged 18 to 58 years old, with an average age of 28.8 [23.0; 37.5] years. There were 96 men and 114 women. All patients were treated in the department number 1 of the communal institution "Zaporizhzhia Regional Clinical Infectious Disease Hospital" of the Zaporizhzhia Regional Council from July 2017 to March 2019. Confirmation of measles diagnosis based on clinical, epidemiological and laboratory data with the determination of IgM immunoglobulins to measles virus was performed according to WHO criteria (2013) [16]. All patients underwent traditional clinical laboratory examinations and instrumental studies according to the indications. In the presence of changes in liver tests, serological tests were performed on the markers of viral hepatitis $B$ and $C$. For the analysis of the frequency and range of complications of measles, depending on the severity of the disease, patients were divided into groups: 178 patients with moderate duration; 32 patients - with severe course of measles.

To evaluate the functional state of the ANS, a method of computer cardiointervalometry with the definition of HRV parameters was used. The research was conducted using the electrocardiographic diagnostic system CardioLab-2000 according to the standard method. The CardioLab-2000 program for recording, storing, analyzing and interpreting cardio heart rate parameters works in the Windows operating system environment and allows for a detailed spectral analysis of HRV characteristics in accordance with the protocol of the European Society of Cardiology Working Group and the North American Society for Cardiac Stimulation and Electrophysiology [17]. The study was conducted on 116 patients with measles and 30 healthy controls. For the analysis of the relationship between the functional state of the ANS with the development of complications, the patients were divided into groups: 78 patients with complicated course and 38 patients with uncomplicated flow of measles.

Statistical processing of the material was carried out using the software «Excel» (Microsoft, USA) and Statistica for Windows 13 (StatSoft Inc., JPZ804I382130ARCN10-J). Descriptive statistics including median and interquartile range - Me [Q25; Q75] were calculated to express the variables, which were not normally distributed. In order to assess the validity of the differences between the quantitative features in the independent groups, the Mann-Whitney criterion was used, and the quality method $x^{2}$ was used between qualitative features. Spearman correlation was used to detect relationships between quantitative features, while Kendal correlation - between quantitative and ordinal values.

\section{Results}

According to the results of the research, it was found that clinical manifestations of measles in adults under present conditions retain typical signs. The presence of a prodromal period of 1 to 6 days, an average of $3.1[2.0 ; 4.1]$ days, body temperature increase to 38.8 $\left[38.0 ; 39.0{ }^{\circ} \mathrm{C}\right.$, cough, scleroconjunctivitis, presence of a maculopapular rash with merging of elements were characteristic. At the same time, a number of clinical signs are significantly more likely to be registered with a severe course of measles than with moderate. Thus, scleroconjunctivitis was accompanied by eye irritation in all the patients with severe course against $118(66.3 \%)$ patients $\left(X^{2}=12.7, P<0.004\right)$ with moderate course; hoarseness in $25(78.1 \%)$ versus $52(29.2 \%)$ patients $\left(X^{2}=23.3, P<0.0001\right)$; hemorrhagic manifestations - in $4(12.5 \%)$ versus $2(1.1 \%)$ patients $\left(X^{2}=9.7, P<0.001\right)$; nausea - in $12(37.5 \%)$ versus $14(7.9 \%)$ patients $\left(X^{2}=17.4, P<0.001\right)$; vomiting - in $10(31.3 \%)$ versus $9(5.1 \%)$ patients $\left(X^{2}=14,1, P<0.001\right)$; the duration of the fever was 9.0 [8.0; 11.0] versus 7.0 [5.0; 8.0] days $(P<0.01)$. A definite feature of measles in adults was the preservation of the Filatov-Koplik signs during the period of rash in $162(77.1 \%)$ patients.

In most adult patients, measles had a complicated flow $(70.5 \%)$, with the spectrum of complications mainly represented by the defeat of the respiratory system $(61.4 \%)$ and the gastrointestinal tract $(43.8 \%)$. The frequency of complications development and their range clearly depended on the severity of the disease. Such complications from the respiratory organs as bronchitis $\left(X^{2}=5.6, P<0.05\right)$ and pneumonia $\left(X^{2}=82.6, P<0.0001\right)$ were more common in patients with severe course of measles. Some patients with severe measles course developed such complications as pulmonary edema and left lung atelectasis (Table 1).

The most severe complications from the respiratory organs arose in two pregnant women. So, for a patient C., 30 years old, who was vaccinated against measles by schedule in childhood, the severe course of measles emerged on the background of a twin pregnancy with gestational age of 26 weeks and was characterized by the development of several complications. From the first days of rash there were clinical manifestations of enteritis, and on the $3^{\text {rd }}$ day of rash against the background of bronchitis there were acute respiratory failure of the II degree, which appeared as a breath to 46 per minute and a decrease in oxygen saturation to $93 \%$. Pulmonary edema was confirmed by X-ray, on the background of the treatment with oxygen therapy in the mask mode in two days, it was possible to achieve a significant positive dynamics, and the complicated course of measles did not affect the course of pregnancy. In another 25-year-old patient who had not been vaccinated against measles 
Table 1. Characteristics of spectrum and frequency of measles complications in adults, abs (\%)

\begin{tabular}{|c|c|c|c|}
\hline \multirow[t]{2}{*}{ Indicator } & \multirow{2}{*}{$\begin{array}{l}\text { Patients } \\
\text { with measles } \\
(n=210)\end{array}$} & \multicolumn{2}{|c|}{ Patients with measles } \\
\hline & & $\begin{array}{l}\text { moderate } \\
\text { course }(n=178)\end{array}$ & $\begin{array}{l}\text { severe course } \\
(n=32)\end{array}$ \\
\hline The presence of complications & $148(70.5 \%)$ & $116(65.2 \%)$ & $32(100 \%)^{*}$ \\
\hline from the respiratory system organs: & $129(61.4 \%)$ & $97(54.5 \%)$ & $32(100 \%)^{*}$ \\
\hline bronchitis & $113(53.8 \%)$ & $96(53.9 \%)$ & $20(62.5 \%)^{*}$ \\
\hline pneumonia & $16(7.6 \%)$ & $1(0.6 \%)$ & $15(46.9 \%)^{*}$ \\
\hline pulmonary edema & $1(0.5 \%)$ & & $1(3.1 \%)$ \\
\hline left lung atelectasis & $1(0.5 \%)$ & & $1(3.1 \%)$ \\
\hline from the gastrointestinal tract: & $92(43.8 \%)$ & $63(35.4 \%)$ & $29(90.6 \%)^{*}$ \\
\hline hepatitis & $89(42.4 \%)$ & $63(35.4 \%)$ & $26(81.3 \%)^{*}$ \\
\hline enteritis & $19(9.0 \%)$ & $7(3.9 \%)$ & $12(37.5 \%)^{*}$ \\
\hline the Mallory-Weiss syndrome & $1(0.5 \%)$ & - & $1(3.1 \%)$ \\
\hline from central nervous system: & $2(1.0 \%)$ & - & $2(6.2 \%)$ \\
\hline serous meningitis & $1(0.5 \%)$ & & $1(3.1 \%)$ \\
\hline encephalopathy, cerebral edema & $1(0.5 \%)$ & & $1(3.1 \%)$ \\
\hline \multicolumn{4}{|l|}{ from the organs of vision: } \\
\hline cyclitis & $1(0.5 \%)$ & - & $1(3.1 \%)$ \\
\hline
\end{tabular}

*: the difference is significant compared with patients with moderate course of measles $(P<0.01)$.

in childhood, measles was on the background of a first pregnancy of 29-30 weeks and the first identified chronic hepatitis $\mathrm{C}$. At the end of the first day of rash there was a tachypnoe to 32 per minute while maintaining oxygen saturation $95 \%$, X-ray diagnosis of bilateral pneumonia. During the next 24 hours, the patient's condition rapidly deteriorated due to the progression of the signs of respiratory failure to grade III, namely, increased tachypnoe to $45-50$ per minute, oxygen saturation decreased to $88 \%$, by X-ray detected signs of left lung atelectasis, clinical manifestations of toxic-hypoxic encephalopathy, in connection with which the patient was transferred to artificial ventilation of the lungs. On the fourth day of rash (the second day of artificial lungs ventilation), preterm labor began, which was conservative through natural birth canal, the baby was born alive. After delivery, control lung radiograph showed regression of left lung atelectasis while maintaining signs of pneumonia. After 6 days of artificial lung ventilation, the positive dynamics of the course of the disease and the radiological picture was recorded. For further treatment, the patient was transferred to the pulmonology department.

Complications from the gastrointestinal tract were recorded in almost half of the adult patients with measles, and the frequency of their development also depended on the severity of the course of the disease. Complications such as hepatitis $\left(X^{2}=6.9, P<0.01\right)$ and enteritis $\left(X^{2}=37.1, P<0.001\right)$ more often developed under severe illness. One patient for 29 years suffered from severe rash with hemorrhagic component, thrombocytopenia at the height of the disease to $70 \times 10^{9} /$, the formation of several complications such as bronchitis, hepatitis, Mallory-Weiss syndrome, which arose on the $3^{\text {rd }}$ day and was manifested by vomiting blood that required a fibrogastroduodenoscopy for diagnostic purposes (Table 1). The development of hepatitis in adult patients with measles was characterized by biochemical changes in the functional state of the liver at the time of hospitalization in the absence of clinical manifestations of hepatitis. In all patients with measles, which was complicated by hepa- titis, an increased activity of ALT in serum was detected, while the level of increase of this indicator depended on the severity of the course of measles. Thus, in patients with a moderate course of activity, the activity of AIAT in

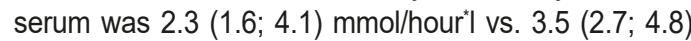
$\mathrm{mmol} /$ hourl in patients with severe course $(P=0.019)$. The presence of a reverse correlation between the activity of ALT in serum and the blood platelet count $(r=-0.38$, $\mathrm{P}<0.05)$ confirms the relationship between the development of hepatitis in adult patients with measles with the severity of the disease. The presence of cytolysis syndrome in almost half of patients was combined with biochemical features of intrahepatic cholestasis. If the level of alkaline phosphatase activity did not depend on the severity of the measles, the level of gamma-glutamyltranspeptidase activity was higher $(P=0.0003)$ with severe measles course than with a moderate course and amounted to 79.2 (56.3; 155.4) unit// against 228.8 (116.8; 379.8) units/ liter. The transient increase in the total bilirubin level to 26.0 and 39.7 micromole/l was recorded in two patients.

During the observation period, only one patient of 52 years reported a complication of measles from the nervous system, namely the development of serous meningitis on the $5^{\text {th }}$ day of rash period with signs of cerebral edema. Eye lesions occurred in a patient of 33 years with a severe course of measles, accompanied by a combination of such complications as acute bronchitis, hepatitis, cyclitis (Table 1).

Analysis of HRV indices in adult patients with measles showed that in the presence of complications, the functional state of the ANS is characterized by a decrease in power in all regulatory units with the development of imbalance in the direction of sympathicotonia, compared with healthy people $(P<0.01)$. In addition, in patients with a complicated course of measles, indicators that characterize the total power of vegetative regulation (SDNN, Total power), the parameter characterizing the humoral effects on ANS (VLF) was lower $(P<0.05)$, and the part of sympathetic effects in the general spectrum of vegetative regulation (LF norm) is higher $(P<0.05)$ than in patients without complications of this infection. Sympathicotonia in patients with complicated flow of measles confirms an increase of $90 \%(P<0.05)$ of the vegetative balance index (LF/HF), compared with healthy people. Compared with patients with complicated course of disease, in patients without complications of measles, the index of vegetative balance did not differ $(P>0.05)$ from the indicator of healthy people, despite an increase $(P<0.01)$ of the part of sympathetic effects and a decrease in the parasympathetic effects in the general spectrum of vegetative regulation $(P<0.01)$, compared with healthy people. It should be noted that in the absence of complications in patients, the power of sympathetic (LF) and parasympathetic (HF) effects were lower $(P<0.01)$ than in healthy subjects, but the spectral parameter reflecting the total power of vegetative regulation (Total power), did not differ statistically $(P>0.05)$ from the indicator of healthy people (Table 2).

The revealed correlation connections confirm the clinical and pathogenetic role of functional changes of the ANS in the formation of measles complications in adults. According to the results of our study, patients with measles most often develop complications from 
the respiratory organs, and the oxygen saturation index has a direct correlation with the parameters of ANS: SDNN ( $r=0.40, P<0.05)$, RMSSD $(r=0.32, P<0.05)$, pNN50 ( $r=0.31, P<0.05)$, HRVT $(r=0.30, P<0.05)$, Total power $(r=0.40, P<0.05)$, VLF $(r=0.39, P<0.05)$, LF $(r=0.29, P<0.05), H F(r=0.28, P<0.05)$. Direct correlation was detected between platelet count and RMSSD $(r=0.51, P<0.01)$. The inverse correlation with HRV parameters has hematological parameters that characterize the development of viral-bacterial complications, namely, the quantitative content of blood leukocytes with the HRVTi index $(r=0.32, P<0.05)$, the share of band neutrophils with parameters SDNN $(r=-0.36, P<0.05)$, RMSSD ( $r=-0.30, P<0.05)$, Total power $(r=-0.37$, $P<0.05)$, VLF $(r=-0.30, P<0.05), L F(r=0.34, P<0.05)$, $\mathrm{HF}(r=0.28, P<0.05)$. The correlation of the functional state of the ANS with the formation of hepatitis in adult patients with measles confirms the inverse correlation of pNN50 with gamma-glutamyltranspeptidase activity $(r=-0.36, P<0.05)$ and alkaline phosphatase $(r=-0.37$, $P<0.05)$.

\section{Discussion}

Data from modern literature indicate that the last epidemic increase in measles morbidity is characterized by prevalence of adult patients not only in European countries [6-8] but also in Asian countries [18]. There are many studies that show a higher incidence of comorbidity in adults, but data on the frequency of individual complications varies greatly $[19,20]$. It is believed that the most frequent complication is the development of pneumonia, but according to various authors, the frequency of pneumonia in adult patients with measles varies from $15.3 \%$ [19] to $57.1 \%$ [20]. According to the results of our study, the frequency of pneumonia in adult patients with measles was $7.6 \%$, but under severe conditions, this figure was $46.9 \%$. In our opinion, certain differences in this indicator in various studies are related to the peculiarities of indications for the hospitalization of patients with measles in different countries. According to the literature, hepatitis in children with measles is developing in isolated cases, and the rate of development of this complication among hospitalized children is $1.4 \%$ [5], whereas in adults this complication is registered in $81 \%$ of hospitalized patients [21]. The results of our research on the incidence of hepatitis show that this figure is $42.4 \%$, but in adults with severe illness it reaches $81.3 \%$. In analyzing the severity of the course of complications, in our opinion, the special attention should be paid to the course of measles in pregnant women. In our study, the extremely severe course of measles with the development of complications from the respiratory system in two pregnant women has been demonstrated, in one case, the pregnancy ended with preterm labor. About the severe course of measles in pregnant women and the adverse effects on the course of pregnancy are reported by other authors [6].

According to modern ideas of changes in vegetative regulation in any disease, it is possible to determine the nature of adaptive reactions, from which the peculiarities of the course of the disease, in particular the infectious, and its consequences depend to a large extent. On the other hand, any pathological process is ac-
Table 2. Comparison of HRV indices in adult measles patients depending on the presence of complications, $\mathrm{Me}\left[\mathrm{Q}_{25} ; \mathrm{Q}_{75}\right]$

\begin{tabular}{|c|c|c|c|}
\hline & \multirow{2}{*}{$\begin{array}{l}\text { Healthy people } \\
(n=30)\end{array}$} & \multicolumn{2}{|c|}{ Patients with measles $(n=116)$} \\
\hline & & $\begin{array}{l}\text { without complications } \\
(\mathrm{n}=38)\end{array}$ & $\begin{array}{l}\text { with complications } \\
(\mathrm{n}=78)\end{array}$ \\
\hline SDNN & $53.4[41.1 ; 63.9]$ & $47.3[36.3 ; 53.0]^{*}$ & $39.5[25.8 ; 45.6]^{*}{ }_{k *}$ \\
\hline RMSSD & $46.8[33.2 ; 63.3]$ & $38.9[29.4 ; 41.7]$ & $28.6[18.9 ; 37.4]^{*}{ }^{*}$ \\
\hline pNN50 & $22.1[9.1 ; 39.3]$ & $14.1[6.1 ; 18.6]$ & $6.6[2.4 ; 15.4]^{*}$ \\
\hline HRVTi & $11.9[10.1 ; 14.7]$ & $8.8[6.5 ; 10.4]^{*}$ & $7.3[5.3 ; 10.7]^{*}$ \\
\hline Total power, $\mathrm{mc}^{2}$ & $2581.8[1815.4 ; 3428.6]$ & $1917.8[1148.8 ; 2656.0]$ & $1423.8[517.5 ; 1868.7]^{*}{ }_{* \star}$ \\
\hline$V L F, m c^{2}$ & $893.9[588.1 ; 1348.8]$ & $789.4[397.1 ; 1383.6]$ & $476.1[215.6 ; 808.0]^{*}:$ \\
\hline $\mathrm{LF}, \mathrm{mc}^{2}$ & $850.9[588.1 ; 1348.8]$ & $380.7[173.8 ; 835.6]^{*}$ & $456.9[126.6 ; 661.6]^{*}$ \\
\hline LF norm, $\%$ & $49.4[34.4 ; 53.9]$ & $57.1[45.9 ; 66.1]^{*}$ & $66.4[55.2 ; 73.4]^{*}{ }_{* *}$ \\
\hline $\mathrm{HF}, \mathrm{mc}^{2}$ & $1008.9[655.7 ; 1597.6]$ & $328.1[126.9 ; 531.3]^{*}$ & $223.4[103.3 ; 482.1]^{*}$ \\
\hline HF norm, \% & $50.7[46.1 ; 65.6]$ & $42.9[33.9 ; 54.1]^{*}$ & $34.1[26.6 ; 46.6]^{*}$ \\
\hline LF/HF & $1.0[0.7 ; 1.3]$ & $1.3[0.8 ; 2.0]$ & $1.9[1.1 ; 2.8]^{*}$ \\
\hline
\end{tabular}

*: the difference is significant compared with healthy people $(P<0.01)$; **: with patients without complications $(P<0.05)$.

companied by vegetative disorders, and the appearance of autonomic dysfunction is an unfavorable background for the emergence of other pathological conditions, in particular complications [22]. In our study, the reduction of power in all regulatory units with the development of imbalance towards sympathicotonia in adult patients with measles with complicated course of illness, suggests the presence of a clinical and pathogenetic link development of complications with disorders of autonomic regulation. Data from modern literature $[10,23]$ demonstrate that the shift in vegetative balance towards sympathetic anions with the decrease in HRV indicates an increase in the pathological process. Therefore, the definition and evaluation of changes in the functional state of the ANS has a strategic significance, since it further provides an opportunity to develop an individual approach in the treatment of the patient [24].

\section{Conclusions}

1. Clinical manifestations of measles in adults under present conditions maintain typical signs, but a certain feature of measles in adults is the preservation of Filatov-Koplik signs during the period of rash $(77.1 \%)$. A number of clinical signs are significantly more likely to be registered with severe course than in the moderate course: scleroconjunctivitis with eye irritation (100.0\% vs. $66.3 \%, P<0.004)$, hoarseness $(78.1 \%$ vs. $29.2 \%$, $\mathrm{P}<0.0001)$, hemorrhagic manifestations $(12.5 \%$ vs. $1.1 \%, \mathrm{P}<0.001)$, nausea (37.5 \% vs. $7.9 \%, \mathrm{P}<0.001)$; vomiting $(31.3 \%$ vs. $5.1 \%, P<0.001)$, longer period of fever $(P<0.01)$.

2. The course of measles in most adult patients $(70.5 \%)$ has a complicated character. The complications from the respiratory system (61.4\%) and the gastrointestinal tract $(43.8 \%)$ are often recorded, the frequency and spectrum of which depend on the severity of the disease. Complications from the nervous system and vision organs develop in single adult patients in severe cases.

3. Violations of the functional state of the ANS play a role in shaping the measles complications in adults. In the presence of complications, the functional state of the ANS is characterized by a decrease in power in all 
regulatory units with the development of imbalance in the direction of sympathicotonia, compared with healthy people $(P<0.01)$. In adult patients with complicated courses, the indicators of total vegetative regulation power (SDNN, Total power), humoral effects (VLF) are lower $(P<0.05)$, and the part of sympathetic effects in the general spectrum of vegetative regulation (LF norm) is higher $(P<0.05)$ than in patients without complications of this infection. Sympathicotonia in patients with complicated course confirms an increase of $90 \%(P<0.05)$ of the LF/HF index, compared with healthy people.

Prospects for further research. Taking into account the data we have received about changes in the functional state of ANS, in our opinion, it is advisable to find a way to correct the pathogenetic treatment of adult patients with measles with complicated course of the disease.

Conflicts of interest: authors have no conflict of interest to declare. Конфлікт інтересів: віАсутній.

Нааійшла Ао редакції / Received: 03.06.2019

Після Аоопрацювання / Revised: 30.10.2019

Прийнято АО Аруку / Accepted: 04.11.2019

Information about authors:

Riabokon Yu. Yu., MD, PhD, DSc, Associate Professor

of the Department of Children Infectious Diseases, Zaporizhzhia State Medical University, Ukraine.

Bilokobyla S. O., Assistant Professor of the Department of Infectious Diseases, Zaporizhzhia State Medical University, Ukraine.

Riabokon 0. V., MD, PhD, DSc, Professor, Head of the Department of Infectious Diseases, Zaporizhzhia State Medical University, Ukraine.

\section{Відомості про авторів:}

Рябоконь Ю. Ю., А-р меА. наук, Аоцент каф. Аитячих інфекційних хвороб, Запорізький державний медичний університет, Україна. Білокобила С. О., асистент каф. інфекційних хвороб,

Запорізький Аержавний меАичний університет, Україна.

Рябоконь О. В., А-р меА. наук, професор, зав. каф. інфекційних

хвороб, Запорізький державний медичний університет, Україна.

\section{Сведения об авторах:}

Рябоконь Ю. Ю., А-р меА. наук, Аоцент каф. Аетских инфекционных болезней, Запорожский государственный меАицинский университет, Украина.

Белокобыла С. А., ассистент каф. инфекционных болезней, Запорожский государственный меАицинский университет, Украина.

Рябоконь Е. В., А-р меА. наук, профессор,

зав. каф. инфекционных болезней, Запорожский

государственный медицинский университет, Украина.

\section{References}

[1] World Health Organization. Regional Office for Europe. (2003): Strategic plan for measles and congenital rubella infection in the European Region of WHO. Copenhagen : WHO Regional Office for Europe. Retrieved from https://apps.who.int/iris/handle/10665/107526

[2] Tsvirkun, O. V., Gerasimova, A. G., Tikhonova, N. T., Turaeva, N. V., \& Pimenova, A. S. (2012). Struktura zabolevshikh kor'yu v period ehliminatsii [The Structure of the Measles Cases in the Period of Elimination] Ehpidemiologiya i vaktsinoprofilaktika, 2, 21-25. [in Russian].

[3] Volianska L. A. (2016). Epidemichni realii koru na Ternopilshchyni [Epidemic realities of measles in the ternopil region]. Aktualna infektolohiia, 2, 98-103. [in Ukrainian]

[4] Timchenko, V. N., Kaplina, T. A., Bulina, O. V., Leonicheva, O. A., Khakizimana, Zh. K., \& Timofeeva, E. V. (2017). Aktual'nye problemy korevoi infektsii [Actual problems of measles]. Pediatriya, 8(3), 120-129. https://doi.org/ 10.17816/ped83120-129. [in Russian].
[5] Kramarov, S. O., Yevtushenko, V. V., Kovaliukh, I. Yu., Kaminska, T. M., Holovach, O. V. (2018). Klinichna kartyna koru v ditei, hospitalizovanykh pid chas spalakhu 2017-2018 rr. [Clinical features of measles in children hospitalized during 2017-2018 outbreak]. Aktual'naya infektologiya, 6(5), 240-245. [in Ukrainian]. https://doi.org/ 10.22141/2312 413x.6.5.2018.146773

[6] Grammens, T., Schirvel, C., Leenen, S., Shodu, N., Hutse, V., da Costa, E. M., \& Sabbe, M. (2017). Ongoing measles outbreak in Wallonia, Belgium, December 2016 to March 2017: characteristics and challenges. Eurosurveillance, 22(17), 5-9. https://doi.org/10.2807/1560-7917. es.2017.22.17.30524

[7] Werber, D., Hoffmann, A., Santibanez, S., Mankertz, A., \& Sagebiel, D. (2017). Large measles outbreak introduced by asylum seekers and spread among the insufficiently vaccinated resident population, Berlin, October 2014 to August 2015. Eurosurveillance, 22(34), 6-13. https://doi.org/10.2807/1560-7917.es.2017.22.34.30599

[8] Lancella, L., Di Camillo, C., Vittucci, A. C., Boccuzzi, E., Bozzola, E., \& Villani, A. (2017). Measles lessons in an anti-vaccination era: public health is a social duty, not a political option. Italian Journal of Pediatrics, 43. https://doi.org/10.1186/s13052-017-0420-6

[9] Laksono, B. M., de Vries, R. D., McQuaid, S., Duprex, W. P., \& de Swart, R. L. (2016). Measles Virus Host Invasion and Pathogenesis. Viruses-Basel, 8(8). https://doi.org/10.3390/v8080210

[10] Mikulets, L. V., \& Malkovych N. M. (2010). Osoblyvosti porushen vehetatyvnoho homeostazu u khvorykh na revmatoidnyi artryt [The peculiarities of vegetative homeostasis in patients with rheumatoid arthritis]. Pathologia, 7(3), 107-109. [in Ukrainian].

[11] Tsoi, E. G., \& Igisheva, L. N. (2003). Osobennosti variabel'nosti serdechnogo ritma u novorozhdennykh detei, perenesshikh khronicheskuyu vnutriutrobnuyu gipoksiyu [Heart rate variability in the assessment of adaptation processes in newborns]. Mat' i ditya, 1, 27-30. [in Russian]

[12] Pseunok, A. A. (2008). Mekhanizmy adaptatsii [Mechanisms of adaptation]. Uspekhi sovremennogo estestvoznaniya, 4. Retrieved from https:// elibrary.ru/download/elibrary_11581941_69281899.pdf

[13] Lysheniuk, S. (2014). Rozlady vehetatyvnoho homeostazu pry dyfterii u ditei [Disorders of vegetative homeostasis in children with diphtheria]. Virusni Khvoroby. Toksoplazmoz. Khlamidioz. Materialy naukovo-praktychnoi konferentsii i plenumu Asotsiatsii infektsionistiv Ukrainy (pp. 336-337). Ternopil. [in Ukrainian].

[14] Furyk O. O., \& Riabokon O. V. (2009). Dynamika spektralnykh pokaznykiv variabelnosti rytmu sertsia u khvorykh na hostryi hepatyt $B$ [Dynamics of spectral parameters of heart rhythm variability in patients with an acute hepatitis B]. Pathologia, 6(2), 114-115. [in Ukrainian].

[15] Pavlenova, O. Yu., Ushenina, L. O., Riabokon, O. V., Mashko, O. P., Furyk, O. O., Ushenina, N. S. ... Firiulina, O. M. (2013). Osoblyvost zmin pokaznykiv funktsionalnoho stanu vehetatyvnoi nervovoi systemy u khvorykh na kir [Peculiarities of changes of autonomic nervous system functional state in patients with measles]. Zaporozhye Medical Journal, 2. 39-41. [in Ukrainian].

[16] WHO Regional Office for Europe. (2012): Surveillance Guidelines for Measles, Rubella and Congenital Rubella Syndrome in the WHO European Region, Updated December 2012. WHO Regional Office for Europe. Retrieved from https://apps.who.int/iris/handle/10665/260123

[17] Malik, M., Camm, A. J., Bigger Jr., J. T., Breithardt, G., Cerutti, S., Cohen, R. J., ... Singer, D. H. (1996). Heart rate variability. standards of measurement, physiological interpretation, and clinical use. European Heart Journal, 17(3), 354-381. https://doi.org/10.1093/oxfordjournals. eurheartj.a014868

[18] Dahanayaka, N. J., Pahalagamage, S., Ganegama, R. M., Weerawansa, P., \& Agampodi, S. B. (2015). The 2013 measles outbreak in sri lanka: Experience from a rural district and implications for measles elimination goals. Infectious Diseases of Poverty, 4(1) https://doi. org/10.1186/s40249-015-0084-7

[19] Monfort, L., Munoz, D., Trenchs, V., Hernandez, S., Garcia, J. J., Aguilar, A. C., .. . Luaces, C. (2010). Measles outbreak in Barcelona. Clinica and epidemiological characteristics. Enfermedades Infecciosas Y Microbiologia Clinica, 28(2), 82-86. https://doi.org/10.1016/j.eimc.2009.05.006

[20] Premaratna, R., Luke, N., Perera, H., Gunathilake, M., Amarasena, P. \& Chandrasena, T. G. A. N. (2017). Sporadic cases of adult measles: A research article. BMC Research Notes, 10(1) https://doi.org/10.1186/ s13104-017-2374-6

[21] Dinh, A., Fleuret, V., \& Hanslik, T. (2013). Liver involvement in adults with measles. International Journal of Infectious Diseases, 17(12) E1243-E1244. https://doi.org/10.1016/j.ijid.2013.06.014

[22] Mikhieieva, T. M., Nechytailo, D. Y., Poniuk, V. V., \& Fomina, T. P. (2018) Features of the vegetative state and arterial pressure level in children with chronic gastroduodenal pathology. Zaporozhye Medical Journal, 20(5), 651-654. https://doi.org/10.14739/2310-1210.2018.5.141662

[23] Inazumi, T., Shimizu, H., Mine, T., \& Iwasaki, T. (2000). Changes in autonomic nervous activity prior to spontaneous coronary spasm in patients with variant angina. Japanese Circulation Journal-English Edition, 64(3), 197-201. https://doi.org/10.1253/jcj.64.197

[24] Vizir-Tronova, O. V. (2017). Cardiovascular aspects and the state of vegetative balance in patients with arterial hypertension associated with dyslipidemia. Zaporozhye Medical Journal 19(5), 540-546. https://doi. org/10.14739/2310-1210.2017.5.110083 